\title{
RESEARCH OF CONSISTENCY AS A STABILITY FACTOR OF COMPANIES IN THE REPUBLIC OF SERBIA
}

\author{
Snežana Kirin ${ }^{1}$ \\ Gordana Gavrić2 ${ }^{\text {(D) }}$ \\ Dragana Vojteški Kljenak ${ }^{3}$
}

DOI: https://doi.org/10.31410/LIMEN.S.P.2019.69

\begin{abstract}
Every organization has got certain forms of behaviours, rules, norms, beliefs and attitudes they apply in their business activities and which become common and recognizable patterns of behaviour of all members in one organization and make its factor of consistency. According to the Denison Model, which the research presented in this paper leans on, mission and the consistency factor represent the stability factor of the organizational culture, a phenomenon of the essential importance for successful business. The aim of this paper is to present the presence of consistency in organizations in the Republic of Serbia through an empirical research and to analyse consistency differences in domestic and foreign companies. Organizational culture is developed on the foundations of national culture, hence noticing these differences is important in order to use the results to enhance organizational culture of domestic companies which, in times of transition, are often faced with survival challenges.
\end{abstract}

Keywords: Consistency, Stability, Organization, Organizational culture, Denison Model, Serbia.

\section{INTRODUCTION}

$\mathrm{T}$ he phenomenon of stability is closely related to the ultimate success of a business organization. According to Denison's model for examining the organizational culture, on which the research of this paper leans, the stability of organizations is achieved by a well-defined mission shared by all members of the community, as well as by precisely defined values and a business system (consistency). A high degree of unity through developing and negotiating a sense of commitment to the enterprise as a long-term goal and a clear definition of certain values and a business system allows companies to manage their reliability, survive in times of crisis and low profits and successfully fight on the market. In this regard, according to Blanchard \& O'Connor (2003) ,perhaps more than ever before, a modern organization must know why it exists and what principles it will work on" (p. 2). According to Denison's model, consistency is determined by three factors: coordination and integration, agreement, and core values, whose presence we will demonstrate by examining the defined attitudes presented in the research section of the paper. Given the fact that values and business systems are based on managerial principles and that they differentiate based on the cultural background they come from, we will point out the difference between domestic and foreign companies operating on the territory of the Republic of Serbia.

\section{CONSISTENCY AS A STABILITY FACTOR}

According to Lamberg, Tikkanen, Nokelainen and Suur-Inkeroin (2005), "Although the flexibility and speed of work have been considered as the sources of competitive advantage in a

\footnotetext{
Innovation Centre of the Faculty of Mechanical Engineering, Belgrade, Kraljice Marije 16, Serbia

Faculty of Business Economics and Entrepreneurship, Belgrade, Mitropolita Petra 8, Serbia

Faculty of Business Economics and Entrepreneurship, Belgrade, Mitropolita Petra 8, Serbia
} 
dynamic environment, research development strategies see consistency (instead of aggression or full speed) as the necessary condition for the survival of a company (e.g. Barnett \& Hansen, 1996; Sheth \& Sisodia, 2002)“ (p. 2). By using the established job practices in organizations and sharing crucial values, an organization is developing efficient processes and routines that will, in the long run, play an important supportive role when it comes to its goals and strategies.

The organization should work to consolidate those values that make it successful. Any shortcomings or negative values also need to be identified, because in addition to values being one of the key success factors, they can also be a cause of failure. In his article, The Theory of Business, Drucker states that the largest number of companies that are in crisis have a system of values and beliefs that is not in line with the requirements of the enterprise (Janicijevic, 1997, p.128). Jovanovic, Miskovic, Sobajic \& Rudic (2011) argue that „often long-used routines and procedures make it impossible to create and use new knowledge, because people are accustomed to using standard procedures and find it difficult to change their habits" (p. 219). The simplest way for an organization to adopt the desired value system and working principle is for their manager to behave accordingly.

Sharing key values and expectations among employees will make it easier to resolve most misunderstandings and other efforts in the functioning of the organization. According to Adizes (2008) ,if there is an internal interconnectedness, mutual trust and respect, which must be a characteristic of a desirable organizational culture, the organization enjoys inner peace" ( $p$. 184). Internal peace and stability give the organization the strength necessary to successfully cope with all the challenges of the environment.

\section{RESEARCH METHODOLOGY AND BASIC HYPOTHESES}

The survey was conducted by applying the written interviewing technique in the form of the Likert scale for measuring attitudes ( 1 - completely disagree, 2 - partly disagree, 3 - neither agree nor disagree, 4 - partly agree, 5 - completely agree), constructed according to Denison's model (1999). The questionnaire was distributed in direct contact with the respondents and via the Facebook social network. The obtained data were analysed and interpreted by applying the IBM SPSS Statistics 21program.

In order to elucidate the factors of consistency in Serbian companies, a research study was conducted on a sample of 1,000 respondents employed in different companies in 29 Serbian cities. The data were collected during 2015. The presented results are a part of the research study of organizational culture in the Republic of Serbia's companies.

Basic research hypotheses are:

1. There is a high consistency level in Serbian companies,

2. Attitudes about the level of consistency in domestic and foreign companies differ.

The following attitudes were examined in the research: The leaders and managers do what they say; There is a characteristic management style and a distinct set of management practices; There is a clear and consistent set of values that governs the way we do business; Ignoring core values will get you in trouble; There is an ethical code that guides our behaviour and tells us right from wrong; When disagreements occur, we work hard to achieve ,win-win” solutions; There is a „strong" culture; It is easy to reach consensus, even on difficult issues and key issues; 
There is a clear agreement about the right way and the wrong way to do things; Our approach to doing business is very consistent and predictable; People from different parts of the organization share a common perspective; It is easy to coordinate projects across different parts of the organization; Working with someone from another part of this organization is not like working with someone from a different organization; There is good alignment of goals across levels. The tables below will only show keywords to indicate the items mentioned.

In order to test Hypothesis 1, aimed at analysing consistency in the company lifecycle, a descriptive analysis was applied. In order to test Hypothesis 2, aimed at analysing differences in the degree of consistency understanding by employees in state- and privately-owned companies, the independent sample t-test was applied.

\section{RESEARCH RESULTS}

\subsection{Sample Structure}

If we look at the structure of the sample according to demographic characteristics, the majority of respondents are men (56\%), while there are slightly less women (42\%), and $2 \%$ of the respondents did not state their gender. The majority of respondents are between 31 and 40 years of age (38\%) and have work experience of 6 to 15 years (39\%). Also, most of them have completed high school (42\%), and even more than half of them are in executive positions (64\%).

Regarding the structure of the sample according to the characteristics of the company in which the employees were surveyed, it should be said that the largest number of respondents is employed in medium-sized companies (33.8\%) and in the services sector (20.4\%). Employees in domestic companies are far more represented (86\%). In addition to those working in private companies (52\%) and state-owned companies (44\%), employees in socially-owned enterprises (4\%), which ceased to exist in the interim, were also surveyed. Namely, in 2015, while the research was in progress, the Privatization Law came out, which stipulates that social capital must be privatized by December 31, 2015. In the meantime, some of them have been privatized, while some of them have been nationalized.

\subsection{Analysis of the Consistency Factors in Companies in the Republic of Serbia}

A descriptive analysis was used to obtain an average rating of the examined consistency attitudes.

Table 1 shows data on mean tendency and standard deviation relating to attitudes describing consistency, for a sample size of $\mathrm{N}=1000$ subjects.

Table 1. Ratings for the "consistency" factor attitudes

\begin{tabular}{|l|c|c|c|c|c|}
\hline \multirow{2}{*}{ Descriptive Statistics } & $\mathbf{N}$ & Minimum & Maximum & Mean & Std. Deviation \\
\cline { 2 - 6 } & 1000 & 1 & 5 & 3,23 & 1,308 \\
\hline do what they say & 1000 & 1 & 5 & 3,47 & 1,188 \\
\hline clear and consistent & 1000 & 1 & 5 & 3,41 & 1,138 \\
\hline ignoring values & 1000 & 1 & 5 & 3,85 & 1,219 \\
\hline ethical code & 1000 & 1 & 5 & 3,65 & 1,246 \\
\hline disagreements & 1000 & 1 & 5 & 3,76 & 1,211 \\
\hline "strong" culture & 1000 & 1 & 5 & 3,41 & 1,254 \\
\hline
\end{tabular}




\begin{tabular}{|c|c|c|c|c|c|}
\hline \multicolumn{6}{|l|}{ Descriptive Statistics } \\
\hline & $\mathbf{N}$ & Minimum & Maximum & Mean & Std. Deviation \\
\hline easy consensus & 1000 & 1 & 5 & 3,24 & 1,209 \\
\hline clear agreement & 1000 & 1 & 5 & 3,42 & 1,129 \\
\hline approach to doing business & 1000 & 1 & 5 & 3,85 & 1,111 \\
\hline common perspective & 1000 & 1 & 5 & 3,08 & 1,454 \\
\hline coordinate & 1000 & 1 & 5 & 3,39 & 1,151 \\
\hline working with someone & 1000 & 1 & 5 & 3,64 & 1,138 \\
\hline good alignment & 1000 & 1 & 5 & 3,48 & 1,144 \\
\hline Valid N (listwise) & 1000 & & & & \\
\hline Average & & & & 3,49 & \\
\hline
\end{tabular}

The average grade of consistency in work in companies in the Republic of Serbia is 3.49, which is between the positions of „,neither agree nor disagree” and ,partly agree”. The result obtained is a slightly higher percentage compared to the neutral attitude about the presence of consistency at work in their companies. With this in mind we can say that the first hypothesis is partially confirmed.

\subsection{Consideration of Differences in the Presence of Consistency Amongst Employees in Domestic and Foreign Companies in Serbia}

Descriptive data for analysing the variables related to the consistency in work in companies are given in Table 2. It shows the number of respondents in each category (domestic / foreign company), mean value in each category, standard deviation from mean value and standard error.

Table 2. Descriptive data - consistency

\begin{tabular}{|c|c|c|c|c|c|}
\hline \multicolumn{6}{|l|}{ Descriptives } \\
\hline & & $\mathbf{N}$ & Mean & Std. Deviation & Std. Error \\
\hline \multirow{3}{*}{ do what they say } & domestic & 859 & 3,21 & 1,321 &, 045 \\
\hline & foreign & 141 & 3,38 & 1,222 & ,103 \\
\hline & total & 1000 & 3,23 & 1,308 & ,041 \\
\hline \multirow{3}{*}{ characteristic style } & domestic & 859 & 3,46 & 1,216 & ,041 \\
\hline & foreign & 141 & 3,53 & 1,004 & ,085 \\
\hline & total & 1000 & 3,47 & 1,188 & ,038 \\
\hline \multirow{3}{*}{ clear and consistent } & domestic & 859 & 3,40 & 1,153 & ,039 \\
\hline & foreign & 141 & 3,50 & 1,046 & ,088 \\
\hline & total & 1000 & 3,41 & 1,138 & ,036 \\
\hline \multirow{3}{*}{ ignoring values } & domestic & 859 & 3,85 & 1,216 & ,041 \\
\hline & foreign & 141 & 3,84 & 1,244 &, 105 \\
\hline & total & 1000 & 3,85 & 1,219 & ,039 \\
\hline \multirow{3}{*}{ ethical code } & domestic & 859 & 3,65 & 1,249 &, 043 \\
\hline & foreign & 141 & 3,70 & 1,229 & ,104 \\
\hline & total & 1000 & 3,66 & 1,246 & ,039 \\
\hline \multirow{3}{*}{ disagreements } & domestic & 859 & 3,74 & 1,222 &, 042 \\
\hline & foreign & 141 & 3,88 & 1,143 & ,096 \\
\hline & total & 1000 & 3,76 & 1,211 & ,038 \\
\hline \multirow{3}{*}{ "strong" culture } & domestic & 859 & 3,36 & 1,251 &, 043 \\
\hline & foreign & 141 & 3,70 & 1,235 & , 104 \\
\hline & total & 1000 & 3,41 & 1,254 &, 040 \\
\hline \multirow{3}{*}{ easy consensus } & domestic & 859 & 3,21 & 1,206 & ,041 \\
\hline & foreign & 141 & 3,39 & 1,218 & ,103 \\
\hline & total & 1000 & 3,24 & 1,209 & ,038 \\
\hline
\end{tabular}




\begin{tabular}{|c|c|c|c|c|c|}
\hline \multicolumn{6}{|l|}{ Descriptives } \\
\hline & & $\mathbf{N}$ & Mean & Std. Deviation & Std. Error \\
\hline \multirow{3}{*}{ clear agreement } & domestic & 859 & 3,40 & 1,147 &, 039 \\
\hline & foreign & 141 & 3,57 & 1,002 &, 084 \\
\hline & total & 1000 & 3,42 & 1,129 &, 036 \\
\hline \multirow{3}{*}{ approach to doing business } & domestic & 859 & 3,88 & 1,101 &, 038 \\
\hline & foreign & 141 & 3,67 & 1,157 & ,097 \\
\hline & total & 1000 & 3,85 & 1,111 & ,035 \\
\hline \multirow{3}{*}{ common perspective } & domestic & 859 & 3,07 & 1,455 &, 050 \\
\hline & foreign & 141 & 3,16 & 1,451 & ,122 \\
\hline & total & 1000 & 3,08 & 1,454 &, 046 \\
\hline \multirow{3}{*}{ coordinate } & domestic & 859 & 3,38 & 1,156 & ,039 \\
\hline & foreign & 141 & 3,48 & 1,119 & ,094 \\
\hline & total & 1000 & 3,39 & 1,151 &, 036 \\
\hline \multirow{3}{*}{ working with someone } & domestic & 859 & 3,63 & 1,152 & 039 \\
\hline & foreign & 141 & 3,73 & 1,048 & ,088 \\
\hline & total & 1000 & 3,64 & 1,138 & ,036 \\
\hline \multirow{3}{*}{ good alignment } & domestic & 859 & 3,46 & 1,160 &, 040 \\
\hline & foreign & 141 & 3,62 & 1,032 & ,087 \\
\hline & total & 1000 & 3,48 & 1,144 & ,036 \\
\hline
\end{tabular}

Considering the fact that the average value of compliance with the surveyed attitudes in most cases is higher in foreign owned companies than in domestic companies, then it is expected that the total average value for all attitudes is higher for foreign companies ownership (3.58) compared to those domestically owned (3.48).

Table 3 shows the results of the independent sample t-test which represent the respondents in domestic and foreign companies. The first part of the table shows the results of Levene's test of equality of variations. The outcome of this test determines whether the t-value is used when the variance equality is implied (Sig $>0.05$ and EVA) or the test value is used when the variance equality is not implied ( $\mathrm{Sig}<0.05$ and EVNA).

Table 3. T-test for domestic and foreign companies

\begin{tabular}{|c|c|c|c|c|c|c|c|c|c|c|}
\hline \multicolumn{11}{|c|}{ Independent Samples Test } \\
\hline & & \multicolumn{2}{|c|}{$\begin{array}{c}\text { Levene's Test } \\
\text { for Equality of } \\
\text { Variances }\end{array}$} & \multicolumn{7}{|c|}{ t-test for Equality of Means } \\
\hline & & \multirow[t]{2}{*}{$\mathbf{F}$} & \multirow[t]{2}{*}{ Sig. } & \multirow[t]{2}{*}{$\mathbf{t}$} & \multirow[t]{2}{*}{ df } & \multirow[t]{2}{*}{$\begin{array}{c}\text { Sig. } \\
\text { (2-tailed) }\end{array}$} & \multirow[t]{2}{*}{$\begin{array}{c}\text { Mean } \\
\text { Difference }\end{array}$} & \multirow[t]{2}{*}{$\begin{array}{l}\text { Std. Error } \\
\text { Difference }\end{array}$} & \multicolumn{2}{|c|}{$\begin{array}{l}\text { 95\% Confidence } \\
\text { Interval of the } \\
\text { Difference }\end{array}$} \\
\hline & & & & & & & & & Lower & Upper \\
\hline \multirow{2}{*}{ do what they say } & EVA & 1,955 & ,162 & $-1,400$ & 998 & ,162 &,- 166 &, 119 &,- 399 &, 067 \\
\hline & EVNA & & & $-1,481$ & 197,629 &, 140 &,- 166 &, 112 &,- 388 &, 055 \\
\hline \multirow{2}{*}{ characteristic style } & EVA & 10,110 & ,002 &,- 625 & 998 &, 532 &,- 067 & ,108 &,- 279 & ,144 \\
\hline & EVNA & & &,- 716 & 213,462 &, 475 &,- 067 & ,094 &,- 253 &, 118 \\
\hline \multirow{2}{*}{$\begin{array}{l}\text { clear and } \\
\text { consistent }\end{array}$} & EVA & 2,161 & ,142 &,- 951 & 998 & ,342 &,- 098 & ,103 &,- 301 & ,105 \\
\hline & EVNA & & & $-1,019$ & 200,040 & ,309 &,- 098 & ,096 &,- 289 & ,092 \\
\hline \multirow{2}{*}{ ignoring values } & EVA &, 078 & ,780 &, 074 & 998 & ,941 &, 008 & ,111 &,- 209 & ,226 \\
\hline & EVNA & & &, 073 & 186,611 & ,942 &, 008 &, 113 &,- 214 & ,230 \\
\hline \multirow{2}{*}{ ethical code } & EVA &, 026 &, 872 &,- 485 & 998 & ,628 &,- 055 &, 113 &,- 277 &, 167 \\
\hline & EVNA & & &,- 490 & 190,577 & ,625 &,- 055 &, 112 &,- 276 &, 166 \\
\hline \multirow{2}{*}{ disagreements } & EVA & 1,531 & ,216 & $-1,253$ & 998 &, 211 &,- 138 &, 110 &,- 354 &, 078 \\
\hline & EVNA & & & $-1,314$ & 196,290 & , 190 &,- 138 &, 105 &,- 345 &, 069 \\
\hline \multirow{2}{*}{ "strong" culture } & EVA &, 430 &, 512 & $-3,008$ & 998 &, 003 &,- 341 &, 113 &,- 564 &,- 119 \\
\hline & EVNA & & & $-3,036$ & 190,235 &, 003 &,- 341 &, 112 &,- 563 &,- 120 \\
\hline
\end{tabular}




\begin{tabular}{|c|c|c|c|c|c|c|c|c|c|c|}
\hline \multicolumn{11}{|c|}{ Independent Samples Test } \\
\hline & & \multicolumn{2}{|c|}{$\begin{array}{l}\text { Levene's Test } \\
\text { for Equality of } \\
\text { Variances }\end{array}$} & \multicolumn{7}{|c|}{ t-test for Equality of Means } \\
\hline & & \multirow[t]{2}{*}{$\mathbf{F}$} & \multirow[t]{2}{*}{ Sig. } & \multirow[t]{2}{*}{$\mathbf{t}$} & \multirow[t]{2}{*}{ df } & \multirow[t]{2}{*}{$\begin{array}{c}\text { Sig. } \\
\text { (2-tailed) }\end{array}$} & \multirow[t]{2}{*}{$\begin{array}{c}\text { Mean } \\
\text { Difference }\end{array}$} & \multirow[t]{2}{*}{$\begin{array}{l}\text { Std. Error } \\
\text { Difference }\end{array}$} & \multicolumn{2}{|c|}{$\begin{array}{l}\text { 95\% Confidence } \\
\text { Interval of the } \\
\text { Difference }\end{array}$} \\
\hline & & & & & & & & & Lower & Upper \\
\hline \multirow{2}{*}{ easy consensus } & EVA & ,004 & ,953 & $-1,602$ & 998 & ,109 &,- 176 &, 110 &,- 391 & 040 \\
\hline & EVNA & & & $-1,592$ & 187,954 & ,113 &,- 176 &, 110 &,- 394 & 042 \\
\hline \multirow{2}{*}{ clear agreement } & EVA & 3,807 & 051 & $-1,743$ & 998 &, 082 &,- 179 & , 102 &,- 380 &, 022 \\
\hline & EVNA & & & $-1,921$ & 205,238 & 056 &,- 179 & ,093 &,- 362 & ,005 \\
\hline \multirow{2}{*}{$\begin{array}{l}\text { approach to doing } \\
\text { business }\end{array}$} & EVA & 2,897 & ,089 & 2,083 & 998 & ,038 &, 210 & ,101 & 012 & ,408 \\
\hline & EVNA & & & 2,011 & 184,106 & ,046 & 210 & ,104 & ,004 & ,416 \\
\hline \multirow{2}{*}{$\begin{array}{l}\text { common } \\
\text { perspective }\end{array}$} & EVA & ,018 & 893 &,- 678 & 998 & ,498 &,- 090 & ,132 &,- 349 &, 170 \\
\hline & EVNA & & &,- 680 & 189,244 & ,497 &,- 090 & ,132 &,- 350 &, 170 \\
\hline \multirow{2}{*}{ coordinate } & EVA & ,148 &, 700 &,- 915 & 998 & ,360 &,- 096 & ,105 &,- 301 &, 110 \\
\hline & EVNA & & &,- 937 & 192,413 &, 350 &,- 096 & ,102 &,- 297 & ,106 \\
\hline \multirow{2}{*}{$\begin{array}{l}\text { working with } \\
\text { someone }\end{array}$} & EVA & 6,095 & ,014 &,- 974 & 998 &, 330 &,- 101 & ,103 &,- 304 & ,102 \\
\hline & EVNA & & & $-1,042$ & 199,741 & 299 &,- 101 & 097 &,- 291 & ,090 \\
\hline \multirow{2}{*}{ good alignment } & EVA & 3,869 & ,049 & $-1,626$ & 998 & ,104 &,- 169 & ,104 &,- 373 &, 035 \\
\hline & EVNA & & & $-1,769$ & 202,708 & 078 &,- 169 & ,095 &,- 357 & 019 \\
\hline
\end{tabular}

The results of the test show that there is a statistically significant difference in the attitude of "There is a 'strong' organizational culture" in favour of foreign companies, and in the attitude „Our approach to business is very consistent and predictable, i.e. there are established working procedures" in favour of domestic companies.

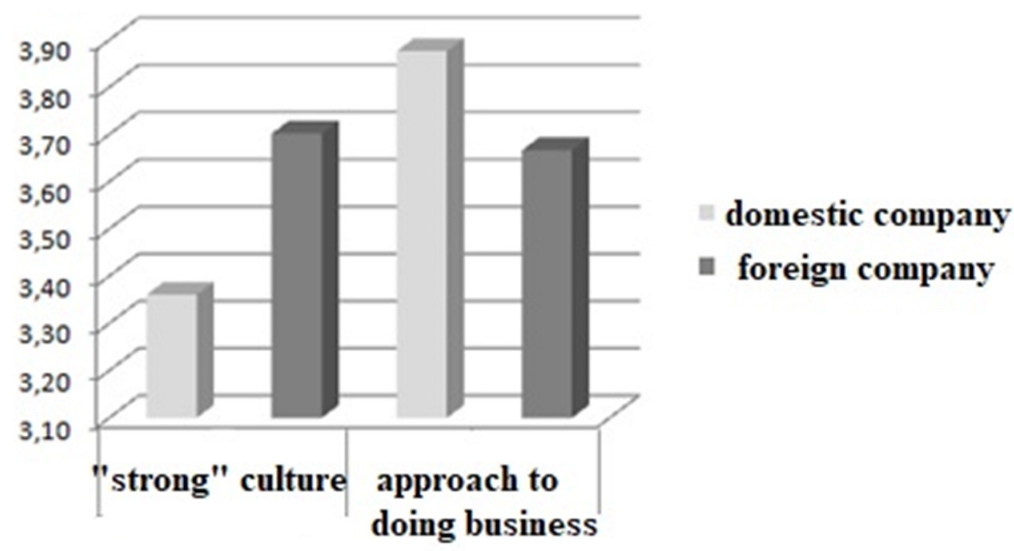

Picture 1. Statistically significant results - consistency

The result of the t-test for the attitude "Our approach to doing business is very consistent and predictable", i.e. there are established working procedures shows the statistical significance of higher scores for domestic companies. The reason for this probably lies in the fact that companies in Serbia have operated for decades in circumstances that implied security and stability, which give the opportunity to operate in a certain established way, without major changes. Thus, in the domestic companies, certain principles and values that are applied in the business and which are difficult to deviate from are deeply rooted. According to Nikolic, Savic, Cockalo, Vukonjanski \& Jovanovic (2011), ,the biggest problem organizational cultures in Serbian companies are faced with is the fact that the new behaviour model is based on old values" (p. 4623). 


\section{FUTURE RESEARCH DIRECTIONS}

Future work could combine results for consistency in business and mission as factors of organizational culture stability, modelled on Denison, which would give a complete picture of the stability of companies in the Republic of Serbia.

\section{CONCLUSION}

The importance of the concept of consistency in business is in the strengthening of the stability factors of business entities.

Based on the results of the research, we can conclude that the first hypothesis that companies in Serbia have a high degree of consistency in work is only partially confirmed since we obtained an average rating of all parameters that determine consistency of 3.49, which represents the value between the neutral attitude (neither agree, nor disagree) and partly agree attitude when it comes to the consistency in work in their companies. As stability is important for the survival and competitiveness of organizations in the contemporary market, it is also a recommendation to companies in Serbia that certain actions should be taken to improve the consistency factor in companies.

The second hypothesis about the existence of differences in the presence of consistency in domestic and foreign companies is only partially confirmed in the case of the examined views „There is a 'strong' organizational culture” and „Our approach to business is very consistent and predictable, i.e. there are established working procedures". According to the respondents, foreign companies have a stronger organizational culture, while in domestic companies, the stabilization of working procedures is more pronounced, i.e. consistency and predictability.

Perceived differences related to certain aspects related to business consistency can serve as a way of improving the performance of domestic companies. Inherited principles and values from the previous period, which are considered useless in the modern times, seem to be the most serious obstacle to the development of domestic companies.

\section{REFERENCES}

Adizes I. (2008). Upravljanje promenama. Novi Sad: Asee

Blanchard K., O’Connor M. (2003). Upravljanje putem vrednosti. Novi Sad: Prometej

Denison, R. D., Neale, S. W. (1999). Denison Organizational Culture Survey. Facilitator Guide, Retrieved October 2014., from http://www.denisonconsulting.com/Docs/DOCS_A-Z/ DOCS_Facilitator_Guide.Pdf

Janicijevic, N. (1997). Organizaciona kultura: kolektivni um preduzeća, Novi Sad: ULIXES, Beograd: Ekonomski fakultet

Jovanovic, P., Miskovic, V., Sobajic, V., Rudic, T. (2011). Upravljanje znanjem i revolucija znanja. Industrija, 1/2011, 213-223

Lamberg J.A., Tikkanen H., Nokelainen T., Suur-Inkeroinen H. (2005). Competitive Dynamics, Strategic Consistency and Organizational Survival. Forthcoming in Strategic Management Journal, 1- 32

Nikolic M., Savic M., Cockalo D, Vukonjanski J., Jovanovic D. (2011). The impact of organizational culture on economic indices-A study in Serbian companies, African Journal of Business Management, 5(11), 4622-4635 